\title{
Basic Marketing Strategies for Improving Business Performance in the Turf and Lawncare Industry 1
}

John J. Haydu and Alan W. Hodges ${ }^{2}$

\section{Introduction}

Marketing can make a difference! Whether selling sod, irrigation or drainage supplies, horticultural chemicals and fertilizers, or lawncare maintenance services, the difference between profitability and bankruptcy could be the presence or absence of a well-defined marketing plan. Numerous studies have firmly established the relationship between marketing and business profitability (Kotler 1999; Cespedes 1995; Wayland 1997). Marketing has broad applications, regardless of the type of business or the type of problems. In this article we discuss five simple marketing strategies that can improve the bottom line performance of your turf or lawncare business.

\section{Five Simple Strategies}

Marketing helps you to understand your present customers better and to uncover innovative ways for reaching new customers. Remember, the customer base is the hub of your business because without customers there simply would be no business. Consequently, you should do everything possible to determine who your customers are and what products and services they want and expect. Successful businesses carry this philosophy to its logical conclusion by striving to go beyond customer satisfaction to customer delight. Exceeding customer expectations is the catalyst that creates a lasting bond between your business and the people you serve. Customer loyalty has many benefits. Philip Kotler (1988), author of Marketing Management, reminds us that loyal customers are satisfied customers and that satisfied customers: (1) are your least expensive customers; (2) buy again and again; (3) talk favorably about your business, which means free advertising; (4) pay less attention to competitors; and (5) tend to buy new products or equipment lines you may add later. The following discussion briefly outlines five marketing management strategies you can employ to satisfy customers while simultaneously improving business performance.

\section{Strategy 1: Monitor Your Inventory}

Perhaps the most basic step in achieving customer satisfaction is to survey items that your current customers are purchasing. Which items are purchased most frequently, or only occasionally? Do you have enough of the most popular items on hand?

1. This is EDIS document FE709, a publication of the Food and Resource Economics Department, Florida Cooperative Extension Service, Institute of Food and Agricultural Sciences, University of Florida, Gainesville, FL. Published March 2008. Please visit the EDIS website at http://edis.ifas.ufl.edu.

2. John J. Haydu, Professor and Associate Extension Specialist, Food and Resource Economics Department, University of Florida, Mid-Florida Research and Education Center, Apopka, FL; and Alan W. Hodges, Associate Extension Specialist, Food and Resource Economics Department, Florida Cooperative Extension Service, Institute of Food and Agricultural Sciences, University of Florida, Gainesville, FL.

The Institute of Food and Agricultural Sciences (IFAS) is an Equal Opportunity Institution authorized to provide research, educational information and other services only to individuals and institutions that function with non-discrimination with respect to race, creed, color, religion, age, disability, sex, sexual orientation, marital status, national origin, political opinions or affiliations. U.S. Department of Agriculture, Cooperative Extension Service, University of Florida, IFAS, Florida A. \& M. University Cooperative Extension Program, and Boards of County Commissioners Cooperating. Larry Arrington, Dean 
Are there other products, supplies, or equipment that you should have in stock? The message is simple-find out! From a customer's point of view, there is nothing more frustrating than traveling across town to obtain needed merchandise only to be disappointed by learning you happen to be "out of stock." When this happens (and it does), a cardinal business rule has been broken, with costly consequences. By not carrying the products or services desired, customers are compelled to look elsewhere. Even worse, alert competitors will do everything they can to add your customers to their customer base. After all, wouldn't you?

\section{Strategy 2: Develop a "Preferred Customer" List}

Keeping customers is the key to surviving and prospering in today's highly competitive marketplace. To stay ahead, businesses will need to distinguish themselves, primarily with superior service. No business can survive long without satisfied customers. Consider these sobering statistics. In their book, "Customer Centered Growth", Whiteley and Hessan (1996) note that 96 percent of unhappy customers never complain and 90 percent of them will never return. In addition, most unhappy customers will tell their individual stories to at least nine other people and 13 percent of those unhappy (former) customers will tell their stories to over 20 people.

One useful strategy is to identify your best customers and communicate to them that they are valued and that you wish a long-lasting relationship. This implies that you have differentiated your customer base into "profitability" categories (e.g., best, average, and worst). Best customers tend to purchase regularly, contribute importantly to your revenue base, and pay on time (their accounts receivable do not exceed 30 days). Those in the lowest category are your most costly clients and should be removed from your customer base.

In the business world, lasting relationships require that both buyers and sellers benefit. Sellers benefit simply by receiving payment for products or services exchanged. Buyers, on the other hand, profit only to the extent that their specific needs or desires are satisfied. A common business problem is that consumer preferences are constantly changing. To keep abreast of these changes, it is critical to maintain open lines of communication between you and your customers. Effective communication is a two-way street - the business and its customers communicating with each other. From the business perspective, a tangible way to communicate customer value is to offer financial incentives for returning to your store, such as providing price discounts on certain product lines, or offering free application or consulting services with large purchases. The rationale is quite simple. Pass on the cost savings acquired from repeat customers or risk losing their business. From the other perspective, customers should know that your business is aware of their expectations and is sincerely concerned with their ultimate satisfaction. A simple but effective way to do this is to survey important clientele at least quarterly to acquire input on key aspects of your business offerings. For example, did the product or service meet their expectations? If not, how could it be improved? What products or services would they like to see that are not currently being offered? This sends a clear message that their input is important, and over time it will provide your business with valuable information on changing consumer preferences.

\section{Strategy 3: Develop a Newsletter}

A newsletter is an excellent way to maintain contact with your customers, particularly your regular customers. A newsletter both personalizes your advertising strategy and looks professional. Your newsletter might incorporate some of the following ideas. Give the newsletter a practical focus by including information based on frequently asked questions (e.g., keep readers abreast of current or impending legislative rulings on the sale of selected pesticides, and provide information on the correct application of fertilizers or the safe handling, use, and disposal of dangerous chemicals). Discuss those items you wish to promote, particularly over-stocked or slow-moving products. Promote your firm by becoming involved with the community and supporting special programs, attending seminars, or devising in-store demonstrations. The point is simple - attract customers by developing a positive image as an educated, responsible, and concerned member of the local community. A newsletter 
offering practical solutions to environmentally sensitive issues will also go a long way towards making that image credible.

\section{Strategy 4: Charge the Right Price}

For the most part, pricing is controlled by the forces of supply and demand. As market forces increase demand, prices increase. Products and services can be divided into two categories: price sensitive and price insensitive. Buyers will shop around for a low price on price-sensitive items. As prices decrease, volumes sold will increase. Purchase decisions on price-insensitive goods are governed more by quality, uniqueness, and appearance, and less by price. The category that products and services fall under depends on how much they are needed or wanted by consumers. Generally speaking, those items that are critical to maintaining day-to-day living will be price insensitive. Conversely, in the event real incomes fall, less essential, leisure-type items will be the first to experience a decline in consumer demand.

Numerous methods are used in setting price, such as charging prices that consumers expect to pay, which is determined through experience based on last year's prices and customers; charging the same or better prices than your competitors; or charging prices based on production or purchase costs. Indeed, costs should be used as a gauge to set the lower bounds of the prices for the products and services you are selling. An effective pricing strategy includes elements of several methods. However, regardless of the policy used, price must be justified by value to the customer. Remember, ultimately, customers determine prices.

\section{Strategy 5: Create a Positive Work Environment}

A final area central to business success is good relations between management and employees. Have your ever watched little league baseball when a few players tried to win the game by themselves? Individual achievement is no substitute for team effort. The same holds true for a business. Too often, managers forget that employees are part of the team, which can destroy a business. Work with your employees and communicate with them regularly.
Educate them on financial aspects of the business, including the value of their service to customers. Give employees financial and educational incentives for doing their jobs well. Remember, employees are your most important resource. A sound employee retention program will pay back big dividends in a work force that is highly motivated and productive.

\section{Concluding Comments}

With competition growing daily, it is increasingly important to exercise good marketing management skills. Without a basic marketing plan, there is simply no way to determine whether the demand you have come to depend on today will be available to you tomorrow. Implementing simple but fundamental measures such as these five marketing strategies can make a positive difference in end-of-year earnings statements.

\section{References}

Cespedes, Frank W. 1995. Concurrent Marketing: Integrating Product, Sales and Service. Boston, MA: Harvard Business School Press.

Kotler, Philip. 1999. Kotler on Marketing: How to Create, Win, and Dominate Markets. New York, NY: The Free Press.

Kotler, Philip. 1988. Marketing Management: Analysis, Planning, Implementation and Control, Sixth Edition. Englewood Cliffs, NJ: Prentice Hall Publishing Company.

Wayland, Robert E., and Paul M. Cole. 1997. Customer Connections: New Strategies for Growth. Boston, MA: Harvard Business School Press.

Whiteley, Richard, and Diane Hessan. 1996. Customer Centered Growth: Five Proven Strategies for Building Competitive Advantage. Menlo Park, CA: Addison-Wesley Publishing Company. 